\title{
PENGARUH MOTIVASI KEPALA SEKOLAH TERHADAP KINERJA GURU DAN PEGAWAI DI SMK MUHAMMADIYAH 3 MAKASSAR
}

\author{
HAMSIAH DJAFAR DAN NURHAFIZAH N. \\ Fakultas Tarbiyah dan Keguruan UIN Alauddin Makassar \\ JI. HM. Yasin Limpo No. 36 Makassar \\ Email: djafar.cia@gmail.com
}

\begin{abstract}
:
This study aims to determine the role of principal as a motivator at SMK Muhammadiyah 3 Makassar, to know the performance of teachers and staff at SMK Muhammadiyah 3 Makassar and to know the influence between principals motivation on teachers performance and employees at SMK Muhammadiyah 3 Makassar. This study used a quantitative approach. The population of this research was all teachers and employees at SMK Muhammadiyah 3 Makassar namely 37 people or it could be sayed total sampling. The data obtained through questionnaire and documentation. It used descriptive and inferential statistics to analyze the data. The results of this research showed that the principal's motivation in SMK Muhammadiyah Makassar are in the moderate category ie 49\%, while the performance of teachers and employees are also in the medium category ie 95\%. The result of inferential statistical analysis shows the value $t_{-}=4.1>t_{-}(0,05(35))=$ 2.021, HO accepted. Based on the results of research and descriptive results inferential, it can be concluded that the principal's motivation affect the performance of teachers and employees.
\end{abstract}

Keywords: Motivasi; kinerja; school principal; teacher and employee

\section{PENDAHULUAN}

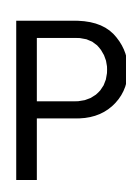

endidikan memegang peranan yang sangat penting dalam proses peningkatan sumber daya manusia. Maju mundurnya suatu bangsa sangat ditentukan oleh kualitas pendidikan bangsa tersebut, sebagaimana tercantum dalam Undang-Undang Sistem Pendidikan Nasional No. 20 Tahun 2003 Pasal 3 tentang fungsi dan tujuan pendidikan nasional, bahwa pendidikan nasional berfungsi mengembangkan kemampuan dan membentuk watak serta peradaban bangsa yang bermartabat dalam rangka mencerdaskan kehidupan bangsa, serta bertujuan untuk berkembangnya potensi peserta didik agar menjadi manusia yang beriman dan bertakwa kepada Tuhan yang Maha Esa, berakhlak mulia, sehat, berilmu, cakap, kreatif, mandiri dan menjadi warga negara yang demokratis serta bertanggung jawab (UURI No.20 tentang Sisdiknas, 2011: 7).

Peningkatan kualitas sumber daya manusia merupakan suatu keniscayaan yang tidak bisa ditawar-tawar lagi untuk dilakukan dengan penuh perencanaan, terarah, intensif, efektif dan efisien dalam proses pembangunan, kalau tidak ingin bangsa ini kalah bersaing dalam pasar bebas tersebut di era global saat ini. 
Pendidikan sebagai totalitas interaksi manusia untuk pengembangan manusia seutuhnya, dan pendidikan merupakan proses yang terus-menerus yang senantiasa dihadapkan pada masalah pengembangan sumber daya manusia (SDM). Oleh karena itu, untuk mencapai maksud tersebut perlu diterapkan suatu sistem manajemen yang memungkinkan keberhasilan pendidikan.

Dalam implementasinya di sekolah, tujuan tersebut di atas dapat diperankan oleh kepala sekolah dalam mengelola pendidikan, baik dalam perencanaan, pengorganisasian, pelaksanaan, pengawasan, dan pengendalian pendidikan di sekolah. Kepala sekolah dituntut untuk dapat mengembangkan berbagai potensi dan kemampuannya dalam aspek manajerial dalam mengelola sumber daya sekolah sesuai dengan kemampuan dan kebutuhannya. Sumber daya sekolah yang sangat penting dalam mengembangkan mutu sekolah adalah guru, dimana seorang guru memiliki tugas dan peran yang sangat besar untuk mengoptimalkan potensi yang dimiliki oleh peserta didik (Susanto, 2016:1).

Diterbitkannya Peraturan Menteri Pendidikan Nasional Nomor 13 tahun 2007 tentang Standar Kepala Sekolah melengkapi peraturan sebelumnya, yaitu UndangUndang Sisdiknas Nomor 20 Tahun 2003 yang diantaranya mengatur bahwa kepala sekolah dalam melaksanakan tugas dan tanggung jawabnya sebagai pemimpin pendidikan harus memiliki kualifikasi, baik kualifikasi umum maupun kualifikasi khusus. Di antara kualifikasi umum yang harus dimiliki oleh kepala sekolah, antara lain: (1) memiliki kualifikasi akademik sarjana (S1) atau Diploma Empat (IV) kependidikan atau nonkependidikan pada perguruan tinggi yang terakreditasi (2) pada waktu diangkat sebagai kepala sekolah berusia setinggitingginya 56 tahun (3) memiliki pengalaman mengajar sekurang-kurangnya 5 (lima) tahun menurut jenjang sekolah masing-masing, kecuali di Taman KanakKanak/Raudhatul Athfal (TK/RA) memiliki pengalaman mengajar sekurangkurangnya 3 (tiga) tahun di TK/RA (4) memiliki pangkat serendah-rendahnya III/c bagi Pegawai negeri sipil dan bagi non-PNS diseterakan dengan kepangkatan yang dikeluarkan oleh yayasan atau lembaga yang berwenang (Andang, 2014: 140-141).

Peran dari kepala sekolah sebagai seorang pemimpin adalah menjadi kunci dari peningkatan atau perkembangan sekolah. Peningkatan kinerja guru dan pegawai dalam pembelajaran dan pelaksanaan tugasnya dapat tercapai apabila kepala sekolah sebagai pemimpin mampu memacu guru dan pegawai dalam meningkatkan kinerjanya dengan sungguh-sungguh dan penuh dedikasi yang tinggi terhadap tugas yang diembannya.

Guru dan pegawai di sekolah merupakan salah satu faktor penentu tinggi rendahnya kualitas pendidikan. Keberhasilan penyelenggaraan pendidikan sangat ditentukan oleh sejauh mana kesiapan guru dan pegawai dalam mempersiapkan peserta didik melalui kegiatan belajar mengajar.

Tidaklah mudah menjadi guru yang mampu menghasilkan lulusan yang berkualitas. Dibutuhkan upaya yang keras untuk mewujudkan pembelajaran yang 
mengarah pada perkembangan potensi peserta didik. Dalam hal ini dibutuhkan guru yang memiliki kinerja mengajar yang baik. Kinerja mengajar mencerminkan bahwa seorang guru telah mampu memenuhi kewajibannya dengan penuh tanggung jawab sebagai seorang profesional.

Pegawai sebagai pelaksana administrasi di sekolah memiliki peran yang cukup strategis dalam rangka memberikan pelayanan administrasi baik kepada pihak internal (guru dan siswa) maupun kepada pihak eksternal (alumni, orang tua dan lembaga lain) sebagai masyarakat dalam suatu sekolah. Maka keberhasilan pelayanan di bidang administrasi sangat ditentukan oleh kinerja yang tinggi dari pegawai, dimana kinerja yang tinggi diidentifikasi melalui kepuasan pengguna jasa, dalam hal ini adalah siswa dan guru.

Keberhasilan pendidikan di sekolah salah satunya ditentukan oleh keberhasilan kepala sekolah dalam mengelola pendidik dan tenaga kependidikan yang berada dalam sistem persekolahan, di antaranya dalam membantu meningkatkan kinerja guru dan pegawai. Kepala sekolah sebagai pelaksana bertanggungjawab atas penyelenggaraan kegiatan pendidikan, administrasi sekolah, pembinaan tenaga kependidikan lainnya dan pendayagunaan serta pemeliharaan (Susanto, 2016: 29).

Berdasarkan pemikiran di atas, seorang pemimpin dalam sebuah lembaga, harus mampu berperan sebagai motivator. Kepala sekolah harus mengimplementasikan perannya sebagai seorang motivator, selain mampu memengaruhi pemimpin juga dibutuhkan untuk memotivasi bawahannya agar lebih bergairah, lebih dinamis, inovatif dalam menjalankan tugas, sehingga diharapkan kinerja guru dan pegawai di sekolah tersebut dapat meningkat.

Permasalahan yang terjadi di SMK Muhammadiyah 3 Makassar sejauh ini minimnya kinerja dari guru dan pegawai yang berada di sekolah tersebut, dimana masih ada beberapa guru dan pegawai yang kurang profesional dan bertanggungjawab dalam menjalankan tugasnya sebagai tenaga pengajar dan tenaga kependidikan. Hal ini tentu dibutuhkan peran seorang pemimpin yang mampu mengontrol dengan baik, menjadi motivator kepada guru dan pegawai agar mereka bisa lebih profesional dalam menjalankan tugas dan tanggungjawabnya.

Masih terdapat guru dan staf yang kurang disiplin dalam menjalankan tugasnya, ketika kepala sekolah tidak berada di tempat maka guru dan pegawai juga terkadang kurang maksimal dalam melaksanakan tugas-tugasnya. Olehnya itu dibutuhkan peran dari kepala sekolah sebagai pemimpin dalam sebuah lembaga pendidikan, yakni sebagai motivator dan diharapkan mampu untuk mengontrol seluruh guru dan pegawai di SMK Muhammadiyah 3 Makassar.

Berdasarkan uraian di atas, maka penulis tertarik untuk melakukan penelitan tentang "Pengaruh Motivasi Kepala Sekolah terhadap Kinerja Guru dan Pegawai di SMK Muhammadiyah 3 Makassar." 


\section{Rumusan Masalah}

Berdasarkan latar belakang di atas, maka yang menjadi rumusan masalah dalam penelitian ini sebagai berikut:

1. Bagaimana gambaran kepala sekolah sebagai motivator di SMK Muhammadiyah 3 Makassar?

2. Bagaimana gambaran kinerja guru dan pegawai di SMK Muhammadiyah 3 Makassar?

3. Apakah terdapat pengaruh yang signifikan antara motivasi kepala sekolah terhadap kinerja guru dan pegawai SMK Muhammadiyah 3 Makassar?

\section{TINJAUAN TEORETIS}

\section{Motivasi Kepala Sekolah}

Istilah motivasi berasal dari bahasa latin yaitu moveree yang berarti bergerak atau menggerakkan. Motivasi diartikan juga sebagai suatu kekuatan sumber daya yang menggerakkan dan mengendalikan perilaku manusia. Motivasi sebagai upaya yang dapat memberikan dorongan kepada seseorang untuk mengambil suatu tindakan yang dikehendaki, sedangkan untuk mengambil suatu tindakan yang dikehendaki, sebagai motif dan daya gerak seseorang untuk berbuat. Karena perilaku seseorang cenderung berorientasi pada tujuan dan didorong oleh keinginan untuk mencapai tujuan tertentu (Yusniar, 2014: 118). Pengertian yang sama diungkapkan oleh Arsyad bahwa motivasi dipandang sebagai dorongan yang menyemangati perilaku, dan mendasari kecenderungan untuk bertahan (Arsyad, dkk., 2006:160). Motivasi merupakan suatu kekuatan yang muncul sebagai penyemangat untuk bekerja atau berkarya sehingga melahirkan sebuah kinerja (hasil kerja). Abraham Maslow, memberikan teori motivasi terdiri dari lima tingkatan kebutuhan ini dikenal dengan sebuah Hirarki Kebutuhan Maslow yaitu; kebutuhan fisiologis, kebutuhan rasa aman, kebutuhan untuk merasa memiliki, kebutuhan akan harga diri, dan kebutuhan mengaktualisasikan diri (Mangkunegara, 2011:94).

Jadi, kesimpulannya adalah apabila guru dan pegawai kebutuhannya tidak terpenuhi maka guru dan pegawai tersebut akan menunjukkan perilaku kecewa. Sebaliknya pula, jika kebutuhannya terpenuhi maka mereka akan memperlihatkan perilaku yang gembira sebagai bentuk dari rasa kepuasannya akan tetapi sebagai tambahan bahwa manusia juga mempunyai kebutuhan yang tidak boleh dilupakan karena ini merupakan kebutuhan yang sangat penting dan mencakup semua kebutuhan di atas yakni kebutuhan beribadah kepada Allah swt, karena segala kegiatan yang dilakukan oleh guru dan pegawai dengan niat bahwa itu semua karena Allah semata.

Motivasi yang dimiliki setiap orang terdiri dari dua yaitu motivasi yang timbul dari dalam dirinya sendiri karena ketertarikan pada sebuah obyek dan motivasi yang berasal dari luar yaitu pemberian dorongan untuk melakukan suatu kegiatan oleh orang lain. Motivasi yang berasal dari dalam diri maupun dari luar sebaiknya 
selalu dimanfaatkan oleh guru untuk meningkatkan semangat kerja guru sehingga dapat memberikan pengaruh yang baik terhadap hasil kerja. Demikian yang diungkapkan oleh Hasibuan (2006:150).

Lebih lanjut Hasibuan menyatakan tujuan motivasi antara lain sebagai berikut; Meningkatkan moral dan kepuasan kerja karyawan, meningkatkan produktivitas kerja karyawan, mempertahankan kestabilan karyawan perusahaan, Peningkatan kedisiplinan karyawan, mengefektifkan pengadaan karyawan, Menciptakan suasana dan hubungan kerja yang baik, meningkatkan loyalitas, kreativitas, dan partisipasi karyawan, meningkatkan tingkat kesejahteraan karyawan, mempertinggi rasa tanggung jawab karyawan terhadap tugas-tugasnya, dan meningkatkan efisiensi penggunaan alat-alat dan bahan baku (Hasibuan, 2006:146).

Berdasarkan pendapat yang telah disampaikan, dapat disimpulkan bahwa pemimpin dalam hal ini kepala sekolah harus dapat memotivasi para guru dan pegawai agar bekerja dengan penuh semangat untuk mencapai tujuan. Begitu juga di sekolah, jika kepala sekolah dapat memotivasi guru dan pegawai sehingga dapat bekerja dengan senang dan penuh semangat, maka diharapkan hasil kerja guru dan pegawai akan optimal.

Dalam konteks pekerjaan, motivasi merupakan salah satu faktor penting dalam mendorong seseorang untuk bekerja. Motivasi adalah kesediaan individu untuk mengeluarkan upaya yang tinggi untuk mencapai tujuan organisasi. Ada tiga elemen kunci dalam motivasi yaitu upaya, tujuan organisasi dan kebutuhan. Upaya merupakan ukuran intensitas. Bila seseorang termotivasi maka ia akan berupaya sekuat tenaga untuk mencapai tujuan, namun upaya yang tinggi akan menghasilkan kinerja yang tinggi (Robbins, 1996:127-128).

Berdasarkan penjelasan di atas maka dapat dipahami bahwa dalam motivasi diperlukan intensitas dan kualitas dari upaya tersebut serta kepala sekolah yang dapat memfokuskan diri pada tujuan dari organisasi. Kebutuhan merupakan kondisi internal yang menimbulkan dorongan yang tidak terpuaskan yang akan menimbulkan tegangan yang merangsang dorongan dari dalam diri individu. Sehingga dorongan tersebut dapat menimbulkan perilaku pencarian untuk menemukan tujuan tertentu. Jika kebutuhan terpenuhi maka akan terjadi tegangan.

Pegawai yang termotivasi berada dalam kondisi tegang dan berupaya untuk mengurangi ketegangan tersebut dengan melakukan upaya menghilangkannya. Dalam memotivasi seseorang bukan sekadar mendorong atau bahkan memerintahkan seseorang melakukan kegiatan atau pekerjaan secara serius, melainkan sebuah seni yang melibatkan berbagai kemampuan dalam mengenali dan mengelola emosi diri sendiri dan orang lain. Paling tidak yang harus diketahui bahwa seseorang melakukan sesuatu karena dorongan oleh motivasinya sendiri 
sehingga dapat menjalankan tugas dan tanggung jawabnya dengan baik agar tercapainya suatu tujuan dari suatu lembaga.

\section{Kinerja Guru dan Pegawai}

Menurut Achmad S. Ruky, kinerja adalah pengalih bahasaan dari kata Inggris performance yang berarti prestasi, pertunjukan, dan pelaksanaan tugas (Ruky, 2002:14). Menurut Henry Bosleywoolf, performance berarti "the execution of an action". Berdasarkan dua pengertian di atas dapat dikatakan bahwa kinerja atau performance berarti tindakan menampilkan atau melaksanakan suatu kegiatan. Oleh karena itu performance sering juga diartikan penampilan kerja atau perilaku kerja. Banyak ahli telah memberikan definisi tentang kinerja, yaitu; Pariata westra, Bateman, Nanang Fattah, Anwar Prabu Mangkunegara (Syukur, 2012:128), dengan kesimpulan bahwa kinerja dapat diartikan suatu kemampuan kerja atau prestasi kerja yang optimal. Dengan demikian istilah kinerja mempunyai pengertian akan adanya suatu tindakan atau kegiatan yang ditampilkan oleh seseorang dalam melaksanakan aktivitas tertentu. Kinerja seseorang akan nampak pada situasi dan kondisi kerja sehari-hari. Aktivitas yang dilakukan oleh seseorang dalam melaksanakan pekerjaannya menggambarkan bagaimana ia berusaha mencapai tujuan yang telah ditetapkan. Kinerja adalah akumulasi dari tiga elemen yang saling berkaitan yaitu keterampilan, upaya, dan sifat-sifat keadaan eksternal. Keterampilan dasar yang dibawa seseorang ke tempat pekerjaan dapat berupa pengetahuan, kemampuan, kecakapan interpersonal dan kecakapan teknis.

Dalam kaitannya dengan kinerja guru, hal ini bisa di lihat dari:

1. Dalam proses belajar mengajar guru sudah mengikuti standar pendidikan yang saat ini digunakan yaitu menggunakan KTSP dan Kurikulum 2013

2. Guru sudah disiplin dalam menjalankan tugasnya sebagai pendidik.

3. Guru sudah memberikan motivasi kepada para siswa untuk lebih giat belajar.

4. Guru juga menggunakan strategi pembelajaran, penggunaan media dan sumber belajar.

5. Guru sudah menyusun administrasi secara tertib (Mulyasa, 2013:75).

Dari pembahasan tersebut maka dapat ditarik kesimpulan bahwa kinerja guru adalah suatu aktifitas guru yang dilakukan dalam rangka membimbing, mendidik, dan melakukan transfer knowledge kepada anak didik sesuai dengan kemampuan keprofesionalan yang dimilikinya dan hasil atau taraf kesuksesan yang dicapai seorang guru dalam bidang pekerjaannya menurut kriteria tertentu dan dievaluasi oleh pimpinan lembaga pendidikan terutama kepala sekolah.

Seorang guru itu harus selalu memperhatikan aspek-aspek kinerjanya. Guru di sini dituntut untuk bisa menyusun rencana pembelajaran, melaksanakan pembelajaran, melaksanakan hubungan antar pribadi, melaksanakan penilaian hasil belajar, melaksanakan program pengayaan dan remedial. 
Bernardin \& Russel mengemukakan bahwa untuk mengukur kinerja pegawai dapat digunakan beberapa aspek atau kriteria, antara lain: kualitas (Quality), kuantitas (Quantity), ketepatan Waktu (Timeliness), efektifitas (Cost effectiveness), dan kemandirian (http://definisiahli.blogspot.co.id).

\section{METODE PENELITIAN}

Penelitian ini merupakan penelitian kuantitatif yang menganalisis hasil penelitian dengan analisis statistik deskripsi dan inferensial. Sesuai dengan judul penelitian, maka penelitian ini berlokasi di SMK Muhammadiyah 3 Makassar. Untuk memperoleh kemudahan dan kejelasan dalam penelitian ini, penulis menggunakan metode kuantitatif.

Populasi dalam penelitian ini adalah tenaga pendidik dan kependidikan di SMK Muhammadiyah 3 Makassar berjumlah 37 orang. Dalam penelitian ini penulis menggunakan teknik Total Sampling yaitu teknik pengambilan sampel apabila semua populasi digunakan sebagai sampel dan dikenal juga dengan istilah sensus. Teknik ini menjadikan semua populasi sebagai sampel.

Untuk mengumpulkan data di lapangan, peneliti menggunakan metode angket dan dokumentasi dengan dua instrument, yaitu; pedoman angket dan dokumen-dokumen atau arsip-arsip di sekolah. Data yang didapat dari instrumen kemudian dianalisis dengan menggunakan analisis deskriptif dan analisis inferensial.

\section{HASIL DAN PEMBAHASAN PENELITIAN}

\section{Pengaruh Motivasi Kepala Sekolah di SMK Muhammadiyah 3 Makassar}

Hasil penelitian menunjukkan bahwa sebanyak 6 responden menilai motivasi kepala sekolah di SMK Muhammadiyah 3 Makassar masih rendah dengan persentase sebesar $16 \%$, selanjutnya sebanyak 18 responden Kepala Sekolah di SMK Muhammadiyah 3 Makassar berada pada kategori sedang dengan persentase 49 \% dan 13 responden menilai Motivasi Kepala Sekolah di SMK Muhammadiyah 3 Makassar berada pada kategori tinggi dengan persentase $35 \%$. Dengan demikian dapat disimpulkan motivasi kepala sekolah di SMK Muhamadiyah 3 Makassar berada pada kategori sedang.

Motivasi merupakan salah satu faktor untuk menjadi daya dorong dalam melakukan sesuatu. Selain faktor kemampuan, motivasi juga dibutuhkan untuk meningkatkan kinerja seseorang.

Secara umum sumber motivasi terbagi menjadi dua yaitu motivasi yang berasal dari dalam diri manusia (internal) dan motivasi yang berasal dari luar diri manusia (eksternal).Motivasi internal yaitu:

\section{Faktor Internal}

Faktor ini berasal dari dalam diri individu yang terdiri atas: 
1. Persepsi individu mengenai diri sendiri, seseorang termotivasi atau tidak untuk melakukan sesuatu banyak tergantung pada proses kognitif berupa persepsi. Persepsi diri seseorang akan mendorong dan mengarahkan perilaku seseorang untuk bertindak.

2. Harga diri dan prestasi, faktor ini mendorong atau mengarahkan individu untuk berusaha agar menjadi pribadi yang mandiri, kuat dan memperoleh kebebasan serta mendapatkan status tertentu dalam lingkungan masyarakat serta dapat mendorong individu untuk berprestasi.

3. Harapan, adanya harapan masa depan. Harapan ini merupakan informasi objektif dari lingkungan yang mempengaruhi sikap dari lingkungan yang mempengaruhi sikap dan perasaan subjektif seseorang. Harapan merupakan tujuan dari perilaku.

4. Kebutuhan, manusia dimotivasi oleh kebutuhan untuk menjadikan dirinya sendiri yang berfungsi secara penuh, sehingga mampu meraih potensinya secara total. Kebutuhan mengarahkan seseorang untuk mencari atau menghindari, mengarahkan dan memberi respon terhadap tekanan yang dialami.

5. Kepuasan kerja, lebih merupakan suatu dorongan efektif yang muncul dalam diri individu untuk mencapai tujuan yang diinginkan dari suatu perilaku.

Faktor Eksternal

Faktor ini berasal dari luar diri individu yang terdiri atas:

1. Jenis dan sifat karyawan, dorongan untuk bekerja pada jenis dan sifat pegawai tertentu dengan objek pegawai yang tersedia akan mengarahkan individu untuk menentukan sikap atau pilihan ke pegawai yang akan ditekuni.

2. Kelompok kerja dimana individu bergabung, kelompok kerja atau organisasi tempat dimana individu bergabung dapat mendorong atau mengarahkan perilaku individu dalam mencapai suatu tujuan perilaku tertentu, peranan kelompok ini dapat membantu individu mendapatkan kebutuhan akan nilainilai kejujuran, kebajikan serta dapat memberikan arti bagi individu sehubungan dengan kiprahnya dalam kehidupan sosial.

3. Situasi lingkungan pada umumnya, setiap individu terdorong untuk berhubungan dengan rasa mempunyai dalam melakukan interaksi secara efektif dengan lingkungannya.

4. Sistem imbalan yang diterima, imbalan merupakan karakteristik atau kualitas dari objek pemuas yang dibutuhkan oleh seseorang yang dapat mempengaruhi motivasi atau dapat mengubah arah tingkah laku dari satu objek ke objek lain yang lebih mempunyai nilai imbalan lebih besar

Berdasarkan hasil penelitian menunjukkan bahwa motivasi seorang pemimpin dalam hal ini kepala sekolah sangat dibutuhkan dan berperan bagi guru 
dan pegawai untuk bersninergi dan menjalankan tugas dengan penuh tanggungjawab dan hasil yang optimal yakni kinerja yang baik.

\section{Gambaran Kinerja Guru dan Pegawai di SMK Muhammadiyah 3 Makassar}

Hasil analisis kategori di atas menunjukkan bahwa sebanyak 2 responden menilai Kinerja Guru dan Pegawai di SMK Muhammadiyah 3 Makassar masih rendah dengan persentase sebesar 5\%, selanjutnya sebanyak 35 responden menilai Kinerja Guru dan Pegawai di SMK Muhammadiyah 3 Makassar berada pada kategori sedang dengan persentase 95\%, dan 0 responden kategori tinggi menilai Kinerja Guru dan Pegawai di SMK Muhammadiyah 3 Makassar.

Dengan demikian dapat disimpulkan bahwa Kinerja Guru dan Pegawai di SMK Muhammadiyah 3 Makassar berada pada kategori sedang yakni $95 \%$.

Ada dua faktor yang mempengaruhi kinerja seseorang yaitu:

1. Faktor kemampuan, secara umum kemampuan ini terbagi menjadi 2 yaitu: Kemampuan potensi (IQ) dan kemampua reality (knowledge dan skill). Seorang guru dan pegawai seharusnya memiliki kemampuan tersebut agar dapat menyelesaikan jenjang pendidikan formal minimal S1 dan memiliki kemmapuan mengajar dalam mata pelajaran.

2. Faktor Motivasi, motivasi terbentuk dari sikap guru dan pegawai dalam menghadapi situasi kerja. Motivasi bagi guru dan pegawai sangat penting untuk mencapai visi dan misi institusi pendidikan. Menjadi guru dan pegawai hendaknya memiliki motivasi yang terbentuk dari awal (by plan), bukan karena keterpaksaan atau kebetulan (by accident)

Pengaruh Motivasi Kepala Sekolah Terhadap Kinerja Guru dan Pegawai di SMK Muhammadiyah 3 Makassar

Berdasarkan hasil statistik inferensial pengujian hipotesis yang memperlihatkan bahwa untuk uji signifikansi yaitu, Jika $t_{\text {hitung }}<t_{\text {tabel }}$ atau $\mathrm{H}_{0}$ diterima, hal ini berarti kostanta persamaan regresi tidak signifikan. Sedangkan $t_{\text {hitung }}>\mathrm{t}_{\mathrm{tab}}$ atau $\mathrm{H}_{\mathrm{o}}$ ditolak atau koefisien regresi bersifat signifikan.

Dari hasil perhitungan diperoleh thitung $=4,1$ sementara tabel $=2,021$ untuk taraf signifikansi 5\%. Karena thitung lebih besar dari tabel maka dapat disimpulkan bahwa Ho ditolak dan $\mathrm{Ha}$ diterima. Maka dapat disimpulkan pengaruh antara motivasi kepala sekolah terhadap kinerja guru dan pegawai di SMK Muhamamdiyah 3 Makassar dalam hal ini variabel $X$ terhadap $Y$ adalah positif memberikan pengaruh yang signifikan.

Berdasarkan hasil penelitian menunjukkan bahwa motivasi seorang pemimpin dalam hal ini kepala sekolah sangat dibutuhkan dan berperan bagi guru dan pegawai untuk bersninergi dan menjalankan tugas dengan penuh tanggungjawab dan hasil yang optimal yakni kinerja yang baik.

\section{KESIMPULAN}


Berdasarkan hasil analisis data dan pembahasan yang telah dijelaskan di sub-bab sebelumnya, maka penelitian ini dapat disimpulkan sebagai berikut:

1. Hasil analisis menunjukkan bahwa sebanyak 6 responden menilai Motivasi Kepala Sekolah di SMK Muhammadiyah 3 Makassar masih rendah dengan persentase sebesar $16 \%$, selanjutnya sebanyak 18 responden Kepala Sekolah di SMK Muhammadiyah 3 Makassar berada pada kategori sedang dengan persentase 49 \% dan 13 responden menilai Motivasi Kepala Sekolah di SMK Muhammadiyah 3 Makassar berada pada kategori tinggi dengan persentase 35 \%. Dengan demikian dapat disimpulkan Motivasi Kepala Sekolah di SMK Muhamadiyah 3 Makassar berada pada kategori sedang.

2. Hasil analisis kategori di atas menunjukkan bahwa sebanyak 2 responden menilai Kinerja Guru dan Pegawai di SMK Muhammadiyah 3 Makassar masih rendah dengan persentase sebesar 5\%, selanjutnya sebanyak 35 responden menilai Kinerja Guru dan Pegawai di SMK Muhammadiyah 3 Makassar berada pada kategori sedang dengan persentase 95\%, dan 0 responden kategori tinggi menilai Kinerja Guru dan Pegawai di SMK Muhammadiyah 3 Makassar. Dengan demikian dapat disimpulkan bahwa Kinerja Guru dan Pegawai di SMK Muhammadiyah 3 Makassar berada pada kategori sedang yaitu $95 \%$.

3. Karena $t_{\text {hitung }}=4,1>t_{0,05(35)}=2,021$ maka $\mathrm{H}_{0}$ diterima. Berdasarkan hasil tersebut, dapat disimpulkan bahwa motivasi kepala sekolah berpengaruh terhadap kinerja guru dan pegawai di SMK Muhammadiyah 3 Makassar.

\section{DAFTAR PUSTAKA}

A. Yusmiar. Manajemen sumber Daya Manusia dalam Peningkatan Kinerja Pegawai. Makassar: Alauddin University Press, 2014.

Ahmad Susanto. Manajemen Peningkatan Kinerja Guru Konsep, Strategi, dan Implementasi, Jakarta: Kencana, 2016.

Anas, Sudijono. Pengantar Statistik Pendidikan. Jakarta: PT. Raja. Grafindo Persada, 2006.

Andang. Manajemen \& Kepemimpinan Kepala Sekolah. Yogyakarta: Ar-Ruzz Media, 2014.

Arifin M, Peran dan Motivasi Kerja. Yogyakarta: Teras, 2010.

Arikunto, Suharsimi. Prosedur Penelitian Suatu Pendekatan Praktek. Jakarta: Rineka Cipta, 1992.

Arikunto, Suharsimi. Manajemen Penelitian Edisi Baru. Jakarta: Rineka Cipta, 2000.

Azhar Arsyad, dkk. Buku Daras, Pengantar Manajemen 2. Makassar: Alauddin University Press, 2006. 
HAMSIAH DJAFAR DAN NURHAFIZAH N.

Basyir, Ahmad Azhar. Garis Besar Sistem Ekonomi Islam. Yogyakarta: BPFE, 1987.Departemen Pendidikan dan Kebudayaan. Kamus Besar Bahasa Indonesia. Jakarta: Balai Pustaka, 1995.

Daryanto, H.M. Administrasi dan Manajemen Madrasah. Jakarta: PT Rineka Cipta, 2013.

Departemen Pendidikan dan Kebudayaan. Kamus Besar Bahasa Indonesia. Jakarta: Balai Pustaka Jakarta, 2005.

Eka Suhartini. Motivasi, Kepuasan Kerja dan Kinerja. Makassar: Alauddin University Press, 2013.

Fathurruhman, Pupuh. Strategi Belajar Mengajar. Bandung: PT Refika Aditama, 2007.

Hasan, MM, M. Iqbal. Pokok - pokok Materi Statistik 2: Statistik Inferensif. Jakarta: Bumi aksara, 2002.

Hasibuan, Malayu S.P. Manajemen Sumber Daya Manusia. Jakarta: Bumi Aksara, 2006.

Hasriani. "Kepemimpinan Kepala Sekolah dalam Mengefektifkan Kinerja Guru di Madrasah Aliyah Negeri Baraka Kabupaten Enrekang" Skripsi Jurusan Manajemen Pendidikan Islam Fakultas Tarbiyah dan Keguruan UIN Alauddin Makassar, 2010.

http://www.risalahislam.com/2014/02/manusia-terbaik-paling-bermanfaatramah.html?m=1. Di akses pukul 17.47 WITA, 16 maret 2017.

http://definisiahli.blogspot.co.id/2013/05/definisi-indikator-kinerja-menurut ahli-html. Diakses pukul 04.00 WITA, 11 Maret 2018.

Iskandar Agung, Yufriadi. Antara Guru, Kepala Sekolah, dan Pengawas. Jakarta: Bestari Buana Murni, 2013.

Kementrian Agama RI, Al-qur'an dan Terjemahnya. Jakarta: PT. Intermasa, 1993.

Kurnia,"Pengaruh Komunikasi Kepemimpinan terhadap Kinerja Guru di SMAN 1 Sungguminasa Kabupaten Gowa", Skripsi Jurusan IImu Komunikasi Fakultas Dakwah dan Komunikasi UIN Aalauddin Makassar, 2013.

M.Fais Satrianegara. Pengembangan Manajemen Sumber Daya Manusia. Makassar: Alauddin University Press, 2013.

Marno dan Triyo Supriyatno, Manajemen dan Kepemimpinan Pendidikan Islam. Bandung: Reika Aditama, 2008.

Mangkunegara, A.A. Anwar Prabu. Manajemen Sunber Daya Manusia Perusahaan. Bandung: Remaja Rosdakarya, 2011.

Mulyasa, Uji Kompetensi dan Penilaian Kinerja Guru. Bandung: Remaja Rosdakarya, 2013. 
Nurita. "Hubungan Motivasi Kerja dengan Kinerja Pegawai di Fakultas Tarbiyah dan Keguruan Universitas Islam Negeri Alauddin Makassar", Skripsi Jurusan Manajemen Pendidikan Islam Fakultas Tarbiyah dan Keguruan UIN Alauddin Makassar,2013

Pahmuddin. "Pengaruh Kepemimpinana Kepala Sekolah terhadap Kinerja Guru di Madrasah Aliyah Negeri 2 Model Makassar", Skripsi Jurusan Manajemen Pendidikan Islam Fakultas Tarbiyah dan Keguruan UIN Alauddin Makassar, 2011.

Putra, Sujudi Ragil. Pengaruh Motivasi Kerja, Lingkungan Kerja dan Pengawasan Kerja Terhadap Produktivitas Kerja Karyawan Pada BMT Bina Ihsanul Fitri Yogyakarta, Skripsi, Prodi Ekonomi UII Yogyakarta, 2006.

Republik Indonesia, Undang-Undang RI No.20 Tahun 2003 tentang Sistem Pendidikan Nasional, Jakarta: Sinar Grafika, 2011.

Ruky, Achmad S. Sistem Manajemen Kinerja. Jakarta: PT. Gramedia Pustaka Utama, 2002.

Robbins, Stephen P. Perilaku Organisasi: Konsep, Kontraversi, Aplikasi. Alih Bahasa Hadayana dan Sarwanto. Jakarta: Ghalia Indonesia, 1996.

S. Margono, Metodologi Penelitian Pendidikan: Komponen MKDK. Jakarta: Rineka Cipta, 2007.

Satrianegara, M.Fais. Pengembangan Manajemen Sumber Daya Manusia. Makassar: Alauddin University Press, 2013.

Siagian, Sondang P. Manajemen Sumber Daya Manusia. Jakarta: Raja Grafindo Persada, 2008.

Simanjuntak, Payaman J. Manajemen dan Evaluasi Kinerja. Jakarta: Lembaga Penerbit Fakultas Ekonomi UI, 2011.

Sugiyono, Metode Penelitian Kuantitatif Kualitatif dan R\&D. Bandung: Alfabeta, 2003.

Suharsini, Prosedur Penelitian Suatu Pendekatan Praktek. Jakarta: Rineka Cipta, 2002.

Sujudi Ragil, Pengaruh Motivasi Kerja, Lingkungan Kerja dan Pengawasan Kerja Terhadap Produktivitas Kerja Karyawan pada BMT Bina Ihsanul Fitri Yogyakarta, Skripsi Prodi Ekonomi UII Yogyakarta, 2006.

Sukmadinata, Nana Syaodih. Landasan Psikologis Proses Pendidikan. Jakarta: Remaja Rosda, 2003.

Supardi. Kinerja Guru. Jakarta: Rajawali Press, 2013.

Susanto, Ahmad. Manajemen Peningkatan Kinerja Guru Konsep, Strategi, dan Implementasi. Jakarta: Kencana, 2016. 
HAMSIAH DJAFAR DAN NURHAFIZAH N.

Susatyo Herlambang. Pengantar Manajemen Cara Mudah Memahami IImu Manajemen. Yogyakarta: Goisyeng Publising, 2013.

Susilo, Martoyo. Manajemen Sumber Daya Manusia. Yogyakarta: BPFE, 2000.

Syamsul Hadi, "Pengaruh Gaya Kepemimpinan terhadap Kinerja Guru dan Staf Tata Usaha MTs Negeri Ngawi", Skripsi Jurusan Manajemen Pendidikan Islam Fakultas Tarbiyah dan Keguruan UIN Sunan Ampel, 2012.

Syukur, Fatah. Manajemen Sumber Daya Pendidikan. Jakarta: Cempaka, 2012.

Wahjosumidjo. Kepemimpinan Kepala Sekolah. Jakarta: PT Raja Grafindo Persada, 2002

Wibowo. Manajemen Kinerja. Jakarta: PT Raja Grafindo Persada, 2013. 